\title{
Biliary Mucosal Barrier and Microbiome
}

\author{
Julien Verdier Tom Luedde Gernot Sellge \\ Department of Internal Medicine III, University Hospital RWTH Aachen, Aachen, Germany
}

\section{Keywords}

PBC - Primary biliary cirrhosis - PSC .

Primary sclerosing cholangitis - Cholecystolithiasis . Gallstones · Bile acids · Microbiome · Microbiota

\section{Summary}

Background: The biliary system is in continuous contact with the complex microbiota of the intestine. Microbial products have recently been proposed as potential triggers for biliary diseases. Methods: The aim of this review is to provide a summary of the current knowledge regarding the role of the biliary and intestinal microbiome in biliary inflammatory diseases. Results: Previously, it was suggested that the healthy biliary system is a sterile organ, while acute cholangitis and cholecystitis may occur from ascending infections. Although non-inflammatory biliary colonization by certain bacteria such as Salmonella spp. has been already recognized since several decades, human and animal studies indicated only very recently that the gallbladder harbors a complex microbiota also under non-pathologic conditions. Novel findings suggested that - similar to the situation in the intestine - the biliary mucosa features a chemical, mechanical, and immunological barrier, ensuring immunological tolerance against commensals. However, microbial triggers might influence acute and chronic inflammatory disease of the biliary system and the whole liver. Conclusion: Although yet undefined, dysbiosis of the biliary or intestinal microbiota rather than a single microorganism may influence disease progression.

\section{Introduction}

Inflammatory diseases of the biliary system encompass clinically distinct conditions involving both genetic and environmental risk factors. While genetic risk factors associated with inflammation of the biliary duct indicate the importance of metabolite transport and immune responses, major environmental factors are commonly considered as microorganisms ascending from the intestinal tract $[1,2]$. However, the exact nature of microbes in the biliary tract in physiological and pathological conditions as well as their role in biliary diseases is only at the beginning of getting deciphered. Different specific bacteria have been associated with biliary diseases but their identification did not lead to major therapeutic improvements. Similar to inflammatory bowel diseases (IBD) [3], it is possible that a local disequilibrium of microbial populations (dysbiosis) may have an important role in biliary inflammation. Numerous studies revealed the importance of the microbiota not only in the gut but also in extraintestinal diseases [4], and pointed to an important role of dysbiosis rather than a role for single microorganisms. In this review, we will describe which microorganisms have been proposed as etiologic agents in biliary inflammatory diseases and discuss the general role of the biliary and intestinal microbiota.

\section{Biliary Mucosal Barrier}

The biliary tree is a network composed of intra- and extrahepatic ducts that drain into the duodenum. Bile ducts are lined by a single layer of biliary epithelial cells, also called cholangiocytes. These are polarized cells with apical and basal poles, joined by tight junctions that limit paracellular transport, and contain microvilli on their apical membrane that allow a 5-fold increase of their luminal surface [5]. Primary bile is produced in hepatocytes and extensively modified by cholangiocytes during transport through the bile ducts [6]. Similar to the intestinal epithelium cells, biliary epithelial cells produce mucins forming a mucus layer and facilitate transcellular immunoglobulin (Ig) A transport into the bile ducts by the polymeric IgA receptor [6].

Human bile contains bacterial cell wall breakdown products including lipopolysaccharides (LPS) and lipoteichoic acid [7, 8], both detectable by innate immune receptors expressed in the biliary tract. Biliary epithelial cells express a wide range of innate immune receptors, including toll-like-receptor (TLR) 1 to TLR6 and TLR9,

\section{KARGER \\ Fax +497614520714

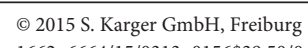

Dr. med. Gernot Sellge

Klinik für Gastroenterologie, Stoffwechselerkrankungen und Internistische Intensivmedizin (Medizinische Klinik III)

Uniklinik RWTH Aachen

Pauwelsstraße 30, 52074 Aachen, Germany gsellge@ukaachen.de 
as well as cell surface and intracellular adaptors such as CD14, MD2, and MyD88 that mediate the signalization pathways and the initiation of inflammatory responses [9-11]. These immune pathways are functional in biliary epithelial cells, as stimulation by LPS activates the transcription factor NF- $\mathrm{kB}$ and the subsequent production of proinflammatory tumor necrosis factor (TNF) [12]. Along with a proinflammatory role, NF- $\kappa \mathrm{B}$ mediates pro-survival signals in cholangiocytes, as the complete disruption of canonical NF- $\kappa B$ leads to biliary apoptosis and cholestatic liver disease [13]. In addition, antimicrobial peptides including cathelicidin and human $\beta$-defensin- 1 and -2 are diffusely expressed in the intrahepatic biliary tree $[14,15]$. Collectively, the formation of a mucin coat and a tight epithelial layer together with the expression of immune receptors and the local production of antimicrobial peptides indicate that the biliary system is programmed to face the possible presence of bacteria. Furthermore, antigen-presenting cells of the liver such as dendritic cells, Kupffer cells, liver sinusoidal endothelial cells, hepatocytes, and stellate cells preferentially mediate tolerizing immunity $[16,17]$.

It has been suggested that the tolerizing environment is required for maintaining immunological homeostasis towards intestinal antigens that enter the liver through the enterohepatic circulation. Whether this tolerogenicity supports non-pathological colonization of microbiota in the biliary system is not known.

\section{Biliary Microbiota}

Bile acids (BAs) have antimicrobial properties by causing bacterial membrane and DNA damage [18]. Hence, it has been assumed that the biliary tract is sterile under non-pathogenic conditions. However, bacteria have been cultured frequently from bile of patients with acute cholangitis or cholecystitis. These bacteria most commonly include bacteria found in the intestinal tract, such as Escherichia coli, Klebsiella, Enterobacter, Pseudomonas, and Citrobacter spp., and their detection has been associated with progression to severe cholangitis and higher mortality rates [19]. Notably, multiple enteric bacteria have developed defense mechanisms conferring BA resistance [18]. These mechanisms have been particularly studied in pathogens that are known to asymptomatically colonize the gallbladder, such as Salmonella spp. and Listeria monocytogenes $[18,20]$. Patients chronically carrying these bacteria represent an important reservoir for new infections. In addition, several studies employing electron microscopy, culturing, and detection of bacterial DNA suggested already more than 20 years ago that multiple bacteria, mainly Gram-negative enterobacteria but also Gram-positives, are present in gallstones in non-inflammatory conditions [21-23].

Only recently it became evident that the biliary system harbors a complex microbiota, most likely also in non-pathogenic situations. This progress was possible by applying more advanced molecular approaches such as pyrosequencing of bacterial 16s rDNA. As such, Wu et al. [24] studied bacterial communities in feces, bile, and gallstones from 29 gallstone patients. Surprisingly, the bacte- rial diversity was higher in the biliary system than in the intestine. On average, about 500 different species could be detected in the bile and gallstones of each patient [24]. There was a large similarity between the intestinal and biliary microbiome, although some significant differences were present: The biliary tract contains relative lower levels of Bacteroidetes (one of the two major gut phyla together with Firmicutes) but higher levels of Proteobacteria, TM7, Tenericutes, Actinobacteria, Thermi, and Cyanobacteria while no differences are detectable for Firmicutes. Similar species richness has been found in a study investigating the bile of 39 patients with primary sclerosing cholangitis (PSC) [25]. However, the majority of the bile samples of the latter study were collected via endoscopic retrograde cholangiopancreatography (ERCP), making intestinal contamination possible.

Other studies investigated the bile and gallbladder mucus of healthy pigs [26] and hamsters infected with the liver fluke Opisthorchis viverrini [27]. Although the diversity of the biliary microbiome was lower than within the intestinal tract in these studies, there were more than 200 [26] and 60 [27] different strains detectable in the biliary system. As in the human study, high numbers of Firmicutes and Proteobacteria but only low numbers of Bacteroidetes were found $[26,27]$. It cannot be excluded that some of the bacterial DNA detected by pyrosequencing resulted from intestinal contamination of dead bacteria or debris that do not reflect the presence of live microbiota. However, in the study of Jimenez et al. [26], the presence of intact bacteria was confirmed by microscopy within the biliary mucosa and up to $4.8 \times 10^{4}$ bacteria $/ \mathrm{ml}$ of bile could be cultured from healthy pigs [26]. Considering the fact that - similar to bacteria in feces - the majority of the biliary microbiota is presumably uncultivable, the bacterial density in the biliary system might be comparable to the microbiota in the proximal parts of the small intestine [28]. The presence of bacteria in bile and gallstone may explain why bile leakage or gallstones lost in the peritoneal cavity during cholecystectomy often cause severe infectious complications [23]. It is important to mention that current pyrosequencing studies described above exclusively studied bile, mucus, or tissue obtained from gallbladders. To our knowledge, it remains unclear whether a similar complex microbiota can be found in the bile ducts.

\section{Impact of Bile Acids on the Intestinal Microbiota}

BAs and the gut microbiota mutually influence each other. Experimentally, mice fed with cholic acid display profound modifications of their gut microbiota [29], and germ-free animals (which are born and raised in a sterile environment and are devoid of intestinal microbiota) have higher concentrations and a reduced diversity of intestinal BAs as compared to conventionally raised animals [30-32]. Gut dysbiosis in patient with liver cirrhosis may also result from the reduced secretion of BAs in the intestine, estimated to be five times less in cirrhosis compared to controls [33]. Due to the metabolism of primary BAs into secondary BAs by intestinal bacteria, the relative amount of secondary BAs in the intestine is 
also reduced in cirrhotic patients. Secondary BAs, notably deoxycholic acid, have potent antimicrobial activity, and their reduction can lead to the overgrowth of some bacteria in the large intestine at the expense of otherwise protective bacteria [34]. A change in the BA pool with a decrease in secondary BAs was also reported in patients with Crohn's disease (CD). These changes were linked to intestinal dysbiosis reflected by a decreased ratio of Faecalibacterium prausnitzii and E. coli. It has been proposed that the loss of the anti-inflammatory effects of secondary BAs on intestinal epithelial cells may enhance chronic inflammation [35].

The importance of secondary BAs in the intestine is reflected by their role in the resistance against colitogenic bacteria. Clostridium difficile are spore-forming bacteria that are a major cause of diarrhea in hospitalized patients treated with antibiotics, owing to i) the broad antibiotic resistance of the spores and ii) the drastic elimination of intestinal bacteria induced by antibiotics. While primary BAs promote the germination of $C$. difficile spores, secondary BAs prevent this and are protective against $C$. difficile infections [36, 37] Antibiotic treatment eliminates gut bacteria, resulting in higher levels of non-processed intestinal primary BAs, notably taurocholic acid, which directly promotes the germination of C. difficile [38]. In contrast, colonization of mice with Clostridium scindens, which metabolizes secondary BAs, protects against C. difficile infection [39].

Changes in diet may influence the intestinal microbiota via its influence on BA production. Using mice prone to develop colitis, Devkota et al. [40] demonstrated that a high-fat diet promotes colitis through a mechanism involving the production of BAs. The high-fat diet increased the production of taurocholic acid which favored the expansion of the bacteria Bilophila wadsworthia that in turn promoted colitis. Interestingly, animal-based diets increase the abundance of bile-tolerant microorganisms, total fecal BA concentration, and levels of B. wadsworthia in humans [41], suggesting that similar mechanisms could be clinically relevant.

\section{Role of Microbiota in Biliary Pathologies}

\section{Gallstones}

Gallstone formation is influenced by genetic and environmental factors such as diet and metabolic processes [42, 43]. Gallstones develop when the cholesterol concentration in bile exceeds the solubilizing capacity or when there is an excess of crystallization promoters. Inflammation-induced biliary mucin production represents an important factor in this context as mucin promotes cholesterol crystallization [44]. In line with the hypothesis of microbial-dependent gallstone formation, genetically identical mice fed with the same lithogenic diet showed different incidences of gallstones when housed in different animal facilities in which animals develop distinct microbiota compositions [45].

Among bacteria associated with gallstones, Helicobacter spp. received particular attention in numerous studies since they have been detected in gallbladder tissue and gallstones [46, 47]. An influence of Helicobacter spp. has been shown in animal studies. As such, in mice fed with a lithogenic diet, cholesterol gallstones oc- curred in $80 \%$ of mice orally gavaged with Helicobacter bilis but not in mice gavaged with Helicobacter pylori or in control mice. However, $H$. bilis could be detected by polymerase chain reaction (PCR) but could not be cultured from gallstones, suggesting an indirect impact on lithogenesis, possibly through the induction of specific immune responses $[45,48]$. Salmonella enterica serovar Typhi can colonize the gallbladder and has been classically associated with gallstones. However, rather than promoting the formation of cholesterol gallstones, there is a body of evidence suggesting that cholesterol gallstones facilitate gallbladder carriage of Salmonella spp. Accordingly, the presence of Salmonella typhi in the gallbladder is significantly higher in mice fed a lithogenic diet than in those fed a normal chow diet [49]. This is explained by the fact that Salmonella spp. can replicate within gallbladder epithelial cells and forms biofilms directly on gallstones $[49,50]$.

A recent study demonstrated that the intestinal microbiota of gallstone patients is significantly different compared to healthy controls [24]. Gallstone patients had higher levels of intestinal bacteria belonging to the phylum Proteobacteria, which includes Escherichia, Salmonella, and Helicobacter spp., all of which were previously associated with gallstones. In contrast, intestines from gallstone patients contained lower levels of Faecalibacterium, Lachnospira, and Roseburia spp. To date it is not known whether these changes are a cause for, a consequence of, or rather associated with cholelithiasis [24].

Lower levels of Faecalibacterium spp. are particularly interesting since $F$. prausnitzii are associated with a protective effect in $\mathrm{CD}$ [51]. Of note, gallstones are more frequent in small $\mathrm{CD}$ than in healthy controls (11-34 vs. 5.5-15\%, respectively) [52], and bile from patients with small bowel CD is more lithogenic than bile from those with colonic CD or ulcerative colitis (UC) [53], hence raising the possibility that development of gallstones may be promoted by gut dysbiosis and/or BA malabsorption.

\section{Primary Biliary Cirrhosis}

Primary biliary cirrhosis (PBC) is an autoimmune disease affecting the small bile ducts. Genetic risk factors largely point to a role of the immune system as they include variants in the region of the human leukocyte antigen (HLA) system as well as variants of the genes encoding the IL(interleukin)-12 receptor and TNF [42]. Importantly, $95 \%$ of $\mathrm{PBC}$ patients produce antimitochondrial antibodies, detectable years before the onset of the disease. These antibodies target the pyruvate dehydrogenase complex E2 (PDC-E2) expressed by biliary epithelial cells [54]. Interestingly, several studies detected cross-reactivity between PDC-E2 and bacterial proteins such as the ATP(adenosine triphosphate)-dependent Clp protease of E. coli [55], the $\beta$-galactosidase of Lactobacillus delbrueckii, a member of the vaginal flora [56], and two yet undefined lipoylated proteins of Novosphingobium aromaticivorans, an environmental Alphaproteobacterium found in soil but also in $25 \%$ of fecal human specimens $[54,57]$. These data may suggest that primary antibody production against bacterial proteins and molecular mimicry of these proteins towards PDC-E2 is responsible for PBC development. This possible mechanism is supported by the clear 


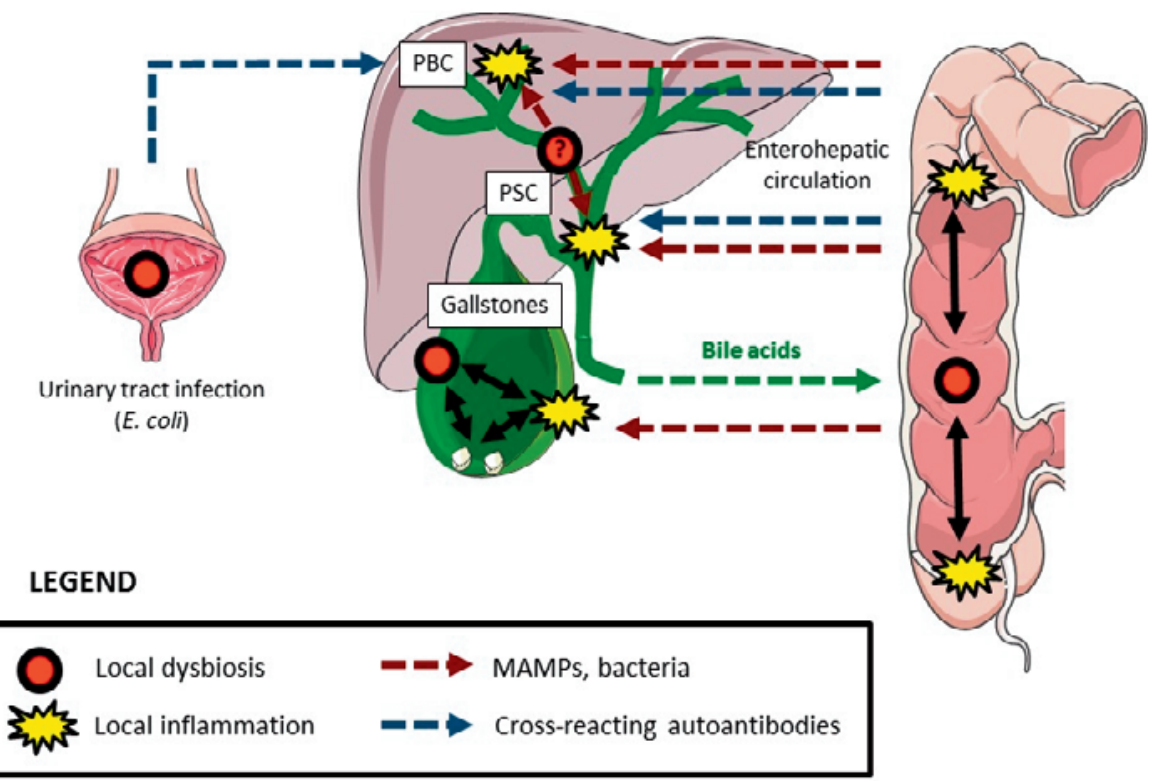

Fig. 1. Hypothetical role of local or intestinal microbial dysbiosis in biliary inflammatory diseases (graph elements have been obtained from the Powerpoint image bank from Servier (Creative commons CC from 3.0 FR)). about a putative gut-derived microbial trigger reaching the biliary epithelium via a 'leaky gut' and the enterohepatic circulation [64]. Indeed, experimental small bowel bacterial overgrowth in rats caused hepatobiliary inflammation resembling histological and cholangiographic features of PSC [65]. Improvement of biliary inflammation by treatment of these rats with mutanolysin, a peptidoglycan-degrading enzyme, suggested an involvement of microbe-associated molecular patterns (MAMPs) in the induction of biliary disease [66]. Additional indications that microbial triggers might be involved in PSC induction or progression come from clinical trials and case reports describing an improvement of liver enzyme serum levels upon antibiotic treatment of PSC patients [64]. However, the strongest genetic risk loci associated with PSC are found in the HLA complex, in regions that only partially overlap those associated with IBD and that are more evocative of autoimmune diseases [42]. Autoantibodies against biliary epithelial cells can be detected in 63\% of patients with PSC [67]. Of note, these autoantibodies include atypical perinuclear antineutrophil cytoplasmic antibodies ( $\mathrm{p}$-ANCAs) that can recognize the autoantigen beta-tubulin isotype 5 (TBB-5) and its bacterial homologue FtsZ, which is expressed by almost all commensal bacteria [68]. In IL-10-deficient animals that develop a spontaneous chronic enterocolitis, p-ANCA, anti-TBB-5, and anti-FtsZ were detectable in presence of the microbiota but not in germ-free animals, suggesting an involvement of microbial triggers in the formation of these antibodies [68]. Furthermore, binding of autoantibodies to biliary epithelial cells results in an upregulation of TLR expression, which in turn might sensitize the biliary tract to microbial products [69].

Recently, one genetic association has been reported that indicates a possible involvement of the microbiota in PSC. A polymorphism that generates a dysfunctional fucusyltransferase-2 (FUT2) protein is associated with PSC [25] and also CD [70]. FUT2 regu- 
lates protein glycosylation, namely fucosylation. Fucosylated proteins are shed into the intestinal [71] and biliary [25] lumen. They have a major influence on microbial metabolic pathways of intestinal commensals and reduce the expression of bacterial virulence genes [71]. The FUT2 genotype influences the microbiota composition of the intestine [70] and of the bile collected during ERCP of PSC patients [25]. Increased abundance of Firmicutes and decreases in Proteobacteria presence and overall species richness in the bile have been associated with dysfunctional FUT2 [25]. Intestinal microbiota in PSC patients has been analyzed in a small cohort. Only minor alterations, i.e. slightly reduced overall diversity and a 2-fold decrease in Clostridiales II abundance, were found in PSC patients compared to controls and to IBD patients without PSC [72]. Altogether, although compelling evidence for specific microbes associated with PSC is still lacking, the examples described above provide some evidence that microbial triggers influence PSC progression.

\section{Conclusion}

During the last years, multiple studies have suggested that biliary diseases (as reviewed here) and chronic liver diseases $[1,2,73]$ are influenced by the microbiota. The intestinal microbiota received major attention since it was demonstrated that proinflammatory MAMPs reach the liver via the enterohepatic circulation and trigger hepatic inflammation. However, the notion that the biliary system by itself may contain a complex microbiota opens the discussion on possible links of biliary dysbiosis with inflammatory diseases of the biliary as well as of the hepatocellular system (fig. 1). Studies of the biliary microbiota are only beginning to emerge, and already indicate that chronic diseases are associated with broad modifications of the microbial content. The knowledge of the impact of the gut and biliary microbiota in biliary disorders is not only important to better understand the etiologies of these diseases but may also provide therapeutic solutions in the future.

\section{Acknowledgements}

Work in the laboratory of G.S. was supported by the German Research Foundation (DFG SE 1122/1 and SFB985 / C3), the European Union's Seventh Framework Programme (FP7/2007-2013) under grant agreement nº305564 (SysmedIBD), and by the START program of the Faculty of Medicine, RWTH Aachen, Germany (START 25/11). Work in the laboratory of T.L. was supported by a Mildred-Scheel Endowed Professorship, a single project grant (110043) from the German Cancer Aid (Deutsche Krebshilfe), and the German Research Foundation (SFB-TRR57 / P06)

\section{Disclosure Statement}

All authors have declared that no competing interests exist.

\section{References}

1 Miyake Y, Yamamoto K: Role of gut microbiota in liver diseases. Hepatol Res 2013;43:139-146.

2 Giannelli V, Di Gregorio V, Iebba V, Giusto M, Schippa S, Merli M, Thalheimer U: Microbiota and the gut-liver axis: bacterial translocation, inflammation and infection in cirrhosis. World J Gastroenterol 2014; 20:16795-16810.

3 Gevers D, Kugathasan S, Denson LA, et al: The treatment-naive microbiome in new-onset Crohn's disease. Cell Host Microbe 2014;15:382-392.

4 Pflughoeft KJ, Versalovic J: Human microbiome in health and disease. Annu Rev Pathol 2012;7:99-122.

5 Si-Tayeb K, Lemaigre FP, Duncan SA: Organogenesis and development of the liver. Dev Cell 2010;18:175-189.

6 Wu CT, Davis PA, Luketic VA, Gershwin ME: A review of the physiological and immunological functions of biliary epithelial cells: targets for primary biliary cirrhosis, primary sclerosing cholangitis and drug-induced ductopenias. Clin Dev Immunol 2004;11:205-213.

7 Sasatomi K, Noguchi K, Sakisaka S, Sata M, Tanikawa $\mathrm{K}$ : Abnormal accumulation of endotoxin in biliary epithelial cells in primary biliary cirrhosis and primary sclerosing cholangitis. J Hepatol 1998;29:409-416.

8 Tsuneyama K, Harada K, Kono N, Hiramatsu K, Zen Y, Sudo Y, Gershwin ME, Ikemoto M, Arai H, Nakanuma Y: Scavenger cells with gram-positive bacterial lipoteichoic acid infiltrate around the damaged interlobular bile ducts of primary biliary cirrhosis. J Hepatol 2001;35:156-163.

$\checkmark$ Chen XM, O'Hara SP, Nelson JB, Splinter PL, Small AJ, Tietz PS, Limper AH, LaRusso NF: Multiple TLRS are expressed in human cholangiocytes and mediate host epithelial defense responses to Cryptosporidium parvum via activation of NF-kappaB. J Immunol 2005; 175:7447-7456.
10 Wang AP, Migita K, Ito M, Takii Y, Daikoku M, Yokoyama T, Komori A, Nakamura M, Yatsuhashi H, Ishibashi H: Hepatic expression of toll-like receptor 4 in primary biliary cirrhosis. J Autoimm 2005;25:85-91.

11 Yokoyama T, Komori A, Nakamura M, Takii Y, Kamihira T, Shimoda S, Mori T, Fujiwara S, Koyabu M, Taniguchi K, Fujioka H, Migita K, Yatsuhashi H, Ishibashi H: Human intrahepatic biliary epithelial cells function in innate immunity by producing IL- 6 and IL-8 via the TLR4-NF-kappaB and -MAPK signaling pathways. Liver Int 2006;26:467-476.

12 Luedde T, Schwabe RF: NF-kappaB in the liver - linking injury, fibrosis and hepatocellular carcinoma. Nat Rev Gastroenterol Hepatol 2011;8:108-118.

13 Luedde T, Heinrichsdorff J, de Lorenzi R, De Vos R, Roskams T, Pasparakis M: IKK1 and IKK2 cooperate to maintain bile duct integrity in the liver. Proc Natl Acad Sci U S A 2008;105:9733-9738.

14 Harada K, Ohba K, Ozaki S, Isse K, Hirayama T, Wada A, Nakanuma Y: Peptide antibiotic human beta-defensin-1 and -2 contribute to antimicrobial defense of the intrahepatic biliary tree. Hepatology 2004;40:925-932.

15 D’Aldebert E, Biyeyeme Bi Mve MJ, Mergey M, Wendum D, Firrincieli D, Coilly A, Fouassier L, Corpechot C, Poupon R, Housset C, Chignard N: Bile salts control the antimicrobial peptide cathelicidin through nuclear receptors in the human biliary epithelium. Gastroenterology 2009;136:1435-1443.

16 Heymann F, Peusquens J, Ludwig-Portugall I, Kohlhepp M, Ergen C, Niemietz P, Martin C, van Rooijen N, Ochando JC, Randolph GJ, Luedde T, Ginhoux F, Kurts C, Trautwein C, Tacke F: Liver inflammation abrogates immunological tolerance induced by Kupffer cells. Hepatology 2015;DOI: 10.1002/hep.27793.
17 Thomson AW, Knolle PA: Antigen-presenting cell function in the tolerogenic liver environment. Nat Rev Immunol 2010;10:753-766.

18 Merritt ME, Donaldson JR: Effect of bile salts on the DNA and membrane integrity of enteric bacteria. J Med Microbiol 2009;58:1533-1541.

19 Csendes A, Burdiles P, Maluenda F, Diaz JC, Csendes P, Mitru N: Simultaneous bacteriologic assessment of bile from gallbladder and common bile duct in control subjects and patients with gallstones and common duct stones. Arch Surg 1996;131:389-394.

20 Hardy J, Francis KP, DeBoer M, Chu P, Gibbs K, Contag $\mathrm{CH}$ : Extracellular replication of listeria monocytogenes in the murine gall bladder. Science 2004;303: 851-853.

21 Wetter LA, Hamadeh RM, Griffiss JM, Oesterle A, Aagaard B, Way LW: Differences in outer membrane characteristics between gallstone-associated bacteria and normal bacterial flora. Lancet 1994;343:444-448.

22 Swidsinski A, Ludwig W, Pahlig H, Priem F: Molecular genetic evidence of bacterial colonization of cholesterol gallstones. Gastroenterology 1995;108:860-864.

23 Hazrah P, Oahn KT, Tewari M, Pandey AK, Kumar K, Mohapatra TM, Shukla HS: The frequency of live bacteria in gallstones. HPB (Oxford) 2004;6:28-32.

24 Wu T, Zhang Z, Liu B, Hou D, Liang Y, Zhang J, Shi P: Gut microbiota dysbiosis and bacterial community assembly associated with cholesterol gallstones in largescale study. BMC Genomics 2013;14:669.

25 Folseraas T, Melum E, Rausch P, et al: Extended analysis of a genome-wide association study in primary sclerosing cholangitis detects multiple novel risk loci. J Hepatol 2012;57:366-375. 
26 Jimenez E, Sanchez B, Farina A, Margolles A, Rodriguez JM: Characterization of the bile and gall bladder microbiota of healthy pigs. Microbiologyopen 2014;3: 937-949.

27 Plieskatt JL, Deenonpoe R, Mulvenna JP, Krause L, Sripa B, Bethony JM, Brindley PJ: Infection with the carcinogenic liver fluke Opisthorchis viverrini modifies intestinal and biliary microbiome. FASEB J 2013;27: 4572-4584.

28 Mowat AM, Agace WW: Regional specialization within the intestinal immune system. Nat Rev Immunol 2014;14:667-685.

29 Islam KB, Fukiya S, Hagio M, Fujii N, Ishizuka S, Ooka T, Ogura Y, Hayashi T, Yokota A: Bile acid is a host factor that regulates the composition of the cecal microbiota in rats. Gastroenterology 2011;141:1773-1781.

-30 Wostmann BS: Intestinal bile acids and cholesterol absorption in the germfree rat. J Nutr 1973;103:982-990.

31 Tremaroli V, Backhed F: Functional interactions between the gut microbiota and host metabolism. Nature 2012;489:242-249.

32 Sayin SI, Wahlstrom A, Felin J, Jantti S, Marschall HU, Bamberg K, Angelin B, Hyotylainen T, Oresic M, Backhed F: Gut microbiota regulates bile acid metabolism by reducing the levels of tauro-beta-muricholic acid, a naturally occurring FXR antagonist. Cell Metab 2013;17:225-235.

33 Kakiyama G, Pandak WM, Gillevet PM, Hylemon PB, Heuman DM, Daita K, Takei H, Muto A, Nittono H, Ridlon JM, White MB, Noble NA, Monteith P, Fuchs M, Thacker LR, Sikaroodi M, Bajaj JS: Modulation of the fecal bile acid profile by gut microbiota in cirrhosis. J Hepatol 2013;58:949-955.

34 Hofmann AF, Eckmann L: How bile acids confer gut mucosal protection against bacteria. Proc Natl Acad Sci U S A 2006;103:4333-4334.

35 Duboc H, Rajca S, Rainteau D, et al: Connecting dysbiosis, bile-acid dysmetabolism and gut inflammation in inflammatory bowel diseases. Gut 2013;62:531-539.

-36 Sorg JA, Sonenshein AL: Bile salts and glycine as cogerminants for Clostridium difficile spores. J Bacteriol 2008;190:2505-2512.

37 Britton RA, Young VB: Role of the intestinal microbiota in resistance to colonization by Clostridium difficile. Gastroenterology 2014;146:1547-1553.

- 38 Theriot CM, Koenigsknecht MJ, Carlson PE Jr, Hatton GE, Nelson AM, Li B, Huffnagle GB, Z Li J, Young VB: Antibiotic-induced shifts in the mouse gut microbiome and metabolome increase susceptibility to Clostridium difficile infection. Nat Commun 2014;5:3114.

- 39 Buffie CG, Bucci V, Stein RR, McKenney PT, Ling L, Gobourne A, No D, Liu H, Kinnebrew M, Viale A, Littmann E, van den Brink MR, Jenq RR, Taur Y, Sander C, Cross JR, Toussaint NC, Xavier JB, Pamer EG: Precision microbiome reconstitution restores bile acid mediated resistance to clostridium difficile. $\mathrm{Na}$ ture 2015;517:205-208.

40 Devkota S, Wang Y, Musch MW, Leone V, FehlnerPeach H, Nadimpalli A, Antonopoulos DA, Jabri B, Chang EB: Dietary-fat-induced taurocholic acid promotes pathobiont expansion and colitis in IL10-/mice. Nature 2012;487:104-108.

41 David LA, Maurice CF, Carmody RN, Gootenberg DB, Button JE, Wolfe BE, Ling AV, Devlin AS, Varma Y, Fischbach MA, Biddinger SB, Dutton RJ, Turnbaugh PJ: Diet rapidly and reproducibly alters the human gut microbiome. Nature 2014;505:559-563.

42 Hirschfield GM, Chapman RW, Karlsen TH, Lammert F, Lazaridis KN, Mason AL: The genetics of complex cholestatic disorders. Gastroenterology 2013;144:13571374.
43 Stokes CS, Krawczyk M, Lammert F: Gallstones: Environment, lifestyle and genes. Dig Dis 2011;29:191-201.

44 Maurer KJ, Carey MC, Fox JG: Roles of infection, inflammation, and the immune system in cholesterol gallstone formation. Gastroenterology 2009;136:425-440.

45 Maurer KJ, Ihrig MM, Rogers AB, Ng V, Bouchard G, Leonard MR, Carey MC, Fox JG: Identification of cholelithogenic enterohepatic Helicobacter species and their role in murine cholesterol gallstone formation. Gastroenterology 2005;128:1023-1033.

46 Kawaguchi M, Saito T, Ohno H, Midorikawa S, Sanji T, Handa Y, Morita S, Yoshida H, Tsurui M, Misaka R, Hirota T, Saito M, Minami K: Bacteria closely resembling Helicobacter pylori detected immunohistologically and genetically in resected gallbladder mucosa. J Gastroenterol 1996;31:294-298.

47 Neri V, Margiotta M, de Francesco V, Ambrosi A, Valle ND, Fersini A, Tartaglia N, Minenna MF, Ricciardelli C, Giorgio F, Panella C, Ierardi E: DNA sequences and proteic antigens of $H$. pylori in cholecystic bile and tissue of patients with gallstones. Aliment Pharmacol Ther 2005;22:715-720.

48 Maurer KJ, Rogers AB, Ge Z, Wiese AJ, Carey MC, Fox JG: Helicobacter pylori and cholesterol gallstone formation in C57L/J mice: a prospective study. Am J Physiol Gastrointest Liver Physiol 2006;290:G175-182.

49 Crawford RW, Rosales-Reyes R, Ramirez-Aguilar Mde L, Chapa-Azuela O, Alpuche-Aranda C, Gunn JS: Gallstones play a significant role in salmonella spp. Gallbladder colonization and carriage. Proc Natl Acad Sci U S A 2010;107:4353-4358.

50 Menendez A, Arena ET, Guttman JA, Thorson L, Vallance BA, Vogl W, Finlay BB: Salmonella infection of gallbladder epithelial cells drives local inflammation and injury in a model of acute typhoid fever. J Infect Dis 2009;200:1703-1713.

51 Sokol H, Pigneur B, Watterlot L, Lakhdari O, Bermudez-Humaran LG, Gratadoux JJ, Blugeon S, Bridonneau C, Furet JP, Corthier G, Grangette C, Vasquez N, Pochart P, Trugnan G, Thomas G, Blottiere HM, Dore J, Marteau P, Seksik P, Langella P: Faecalibacterium prausnitzii is an anti-inflammatory commensal bacterium identified by gut microbiota analysis of Crohn disease patients. Proc Natl Acad Sci U S A 2008;105: 16731-16736.

52 Gizard E, Ford AC, Bronowicki JP, Peyrin-Biroulet L: Systematic review: The epidemiology of the hepatobiliary manifestations in patients with inflammatory bowel disease. Aliment Pharmacol Ther 2014;40:3-15.

53 Pereira SP, Bain IM, Kumar D, Dowling RH: Bile composition in inflammatory bowel disease: ileal disease and colectomy, but not colitis, induce lithogenic bile. Aliment Pharmacol Ther 2003;17:923-933.

54 Kaplan MM, Gershwin ME: Primary biliary cirrhosis. New Engl J Med 2005;353:1261-1273.

55 Baum H, Bogdanos DP, Vergani D: Antibodies to Clp protease in primary biliary cirrhosis: possible role of a mimicking T-cell epitope. J Hepatol 2001;34:785-787.

56 Bogdanos DP, Baum H, Okamoto M, Montalto P, Sharma UC, Rigopoulou EI, Vlachogiannakos J, Ma Y, Burroughs AK, Vergani D: Primary biliary cirrhosis is characterized by IgG3 antibodies cross-reactive with the major mitochondrial autoepitope and its lactobacillus mimic. Hepatology 2005;42:458-465.

57 Selmi C, Balkwill DL, Invernizzi P, Ansari AA, Coppel RL, Podda M, Leung PS, Kenny TP, Van De Water J, Nantz MH, Kurth MJ, Gershwin ME: Patients with primary biliary cirrhosis react against a ubiquitous xenobiotic-metabolizing bacterium. Hepatology 2003;38: 1250-1257.
8 Burroughs AK, Butler P, Sternberg MJ, Baum H: Molecular mimicry in liver disease. Nature 1992;358:377378.

59 Corpechot C, Chretien Y, Chazouilleres O, Poupon R: Demographic, lifestyle, medical and familial factors associated with primary biliary cirrhosis. J Hepatol 2010; 53:162-169.

60 Mattner J, Savage PB, Leung P, Oertelt SS, Wang V, Trivedi O, Scanlon ST, Pendem K, Teyton L, Hart J, Ridgway WM, Wicker LS, Gershwin ME, Bendelac A: Liver autoimmunity triggered by microbial activation of natural killer T cells. Cell Host Microbe 2008;3:304-315.

61 Bogdanos DP, Vergani D: Bacteria and primary biliary cirrhosis. Clin Rev Allergy Immunol 2009;36:30-39.

62 Hiramatsu K, Harada K, Tsuneyama K, Sasaki M, Fujita S, Hashimoto T, Kaneko S, Kobayashi K, Nakanuma Y: Amplification and sequence analysis of partial bacterial 16S ribosomal RNA gene in gallbladder bile from patients with primary biliary cirrhosis. J Hepatol 2000;33:9-18.

63 Eaton JE, Talwalkar JA, Lazaridis KN, Gores GJ, Lindor KD: Pathogenesis of primary sclerosing cholangitis and advances in diagnosis and management. Gastroenterology 2013; 145:521-536.

64 Tabibian JH, Talwalkar JA, Lindor KD: Role of the microbiota and antibiotics in primary sclerosing cholangitis. Biomed Res Int 2013;2013:389537.

65 Lichtman SN, Keku J, Clark RL, Schwab JH, Sartor RB: Biliary tract disease in rats with experimental small bowel bacterial overgrowth. Hepatology 1991;13:766772 .

66 Lichtman SN, Okoruwa EE, Keku J, Schwab JH, Sartor RB: Degradation of endogenous bacterial cell wall polymers by the muralytic enzyme mutanolysin prevents hepatobiliary injury in genetically susceptible rats with experimental intestinal bacterial overgrowth. J Clin Invest 1992;90:1313-1322.

$67 \mathrm{Xu}$ B, Broome U, Ericzon BG, Sumitran-Holgersson S: High frequency of autoantibodies in patients with primary sclerosing cholangitis that bind biliary epithelial cells and induce expression of CD44 and production of interleukin 6. Gut 2002;51:120-127.

68 Terjung B, Sohne J, Lechtenberg B, Gottwein J, Muennich M, Herzog V, Mahler M, Sauerbruch T, Spengler $\mathrm{U}$ : p-ANCAs in autoimmune liver disorders recognise human beta-tubulin isotype 5 and cross-react with microbial protein FtsZ. Gut 2010;59:808-816.

69 Karrar A, Broome U, Sodergren T, Jaksch M, Bergquist A, Bjornstedt M, Sumitran-Holgersson S: Biliary epithelial cell antibodies link adaptive and innate immune responses in primary sclerosing cholangitis. Gastroenterology 2007;132:1504-1514.

70 Rausch P, Rehman A, Kunzel S, Hasler R, Ott SJ, Schreiber S, Rosenstiel P, Franke A, Baines JF: Colonic mucosa-associated microbiota is influenced by an interaction of Crohn disease and FUT2 (Secretor) genotype. Proc Natl Acad Sci U S A 2011;108:19030-19035.

71 Pickard JM, Maurice CF, Kinnebrew MA, Abt MC, Schenten D, Golovkina TV, Bogatyrev SR, Ismagilov RF, Pamer EG, Turnbaugh PJ, Chervonsky AV: Rapid fucosylation of intestinal epithelium sustains host-commensal symbiosis in sickness. Nature 2014;514:638-641.

72 Rossen NG, Fuentes S, Boonstra K, D’Haens GR, Heilig HG, Zoetendal EG, de Vos WM, Ponsioen CY: The mucosa-associated microbiota of PSC patients is characterized by low diversity and low abundance of uncultured clostridiales II. J Crohns Colitis 2015;9:342-348.

73 Roderburg C, Luedde T: The role of the gut microbiome in the development and progression of liver cirrhosis and hepatocellular carcinoma. Gut Microbes 2014;5:441-445. 